\title{
BEHAVIOUR OF TRACE ELEMENTS DURING THE NATURAL EVAPORATION OF SEA WATER: CASE OF SOLAR SALT WORKS OF SFAX SALINE (S.E OF TUNISIA)
}

\author{
R. AMDOUNI
}

Received: $12 / 12 / 08$

Accepted: 30/12/08
Laboratory of analysis,

General Company of Tunisian saline, CO.TU.SAL

Gabes Road Km 0.5, P.O Box 86

3018 Sfax, Tunisia

*to whom all correspondence should be addressed: e-mail: ridam@cotusal.com.tn

\begin{abstract}
We have carried out a geochemical study on the behaviour of certain trace elements during the evaporative concentration of free brines (salinity from 41 to $400 \%$ ) of the solar salt works of Sfax saline (S.E of Tunisia). The elements concerned by this survey are Zinc, Cadmium, Manganese, Molybdenum, Lead, Copper, Aluminium, Iron and Barium. Adequate analytical techniques, adapted to this environment of high salinity, have been used to follow the evolution of the concentration of concerned elements in brines subjected to the evaporation. The results obtained have been presented in function of concentration factor calculated on the basis of the Lithium content in seawater (Coast of Sfax) and those in the brines of salt works.

During the evaporation process, the concentration of trace elements in brines was affected by the evaporation phenomenon for the same reason as the major elements. Nevertheless, their concentrations remain very weak and don't reach their saturation doorsteps. The participation of these elements in the mineral phases can take place only by co-precipitation with saline paragenesis. It is the case of Zinc that can precipitate with Sulphates Salts, the Cadmium, Barium and Copper with Carbonate and Gypsum, the Manganese and the Molybdenum with Potassium Salts; others like Iron and Aluminium, are characterized by a very complex behaviour and are subjected, therefore to effects others than those of the evaporation and the co-precipitation. We can mention the activity of the biological system and adsorption phenomena, in particular, on the organic and mineral particles. They are frequent in ponds where brines are not yet very concentrated; allowing an important biological productivity. Contents in these elements are then variable and very dependent on the growth and the physiological state of the organic matter. These micro-organisms use some metals in their metabolic activities, and notably those that act like vitamin factors. The analysis of sediment and algae sampled from the first ponds of the saline, shows that they are capable as well to fix some important quantities of trace elements. The liberation of these elements by deterioration of organic matter, provoke the important fluctuations of their contents in free brines. In basins where the biologic activity is very limited because of the increase of brines salinity, the evolution of the concentration of trace elements translate the only effect of the evaporation, counterbalanced by adsorption phenomenon and the co-precipitation with the salts deposit.
\end{abstract}

KEYWORDS: Brines, salinity, salt, salt works, concentration factor, saturation, biological system, adsorption, algae co-precipitation, saline paragenesis. 


\section{INTRODUCTION}

Solar Salt works of Sfax saline were installed in the south of Sfax City. They cover nearly 1500 hectares area divided on several ponds along seacoast about $12 \mathrm{~km}$ (Figure 1). From the sea, the initial solutions (salinity $\approx 40 \%$ ) are progressively concentrated; to reach a very advanced stage rarely reached in the nature (salinity $\approx 400 \%$ ). During their movement between the different ponds, brines let precipitate several evaporative facies, beginning by carbonates until the precipitation of potassium and Magnesium salts (Amdouni et al., 1990). This evolution results in very important variations in concentrations and the behaviour of dissolved elements. These variations, answer to several effects, which the enrichment by evaporation and the impoverishment by precipitation are the most important factors. Other local effects can intervene and are generally responsible for the local variations that mark the ionic concentrations of metal traces. We can mention the biologic activity, the adsorption on the organic and mineral particles.

After concentration in preparatory ponds, we obtained saturated brine (density $\approx 1.220$ ) are used to nourish the crystallising pond where halite crystallises. Brines having already precipitated their sodium chlorides (density $\approx 1.255$ ) were also evaporated to obtain magnesium brine (density > 1.330).

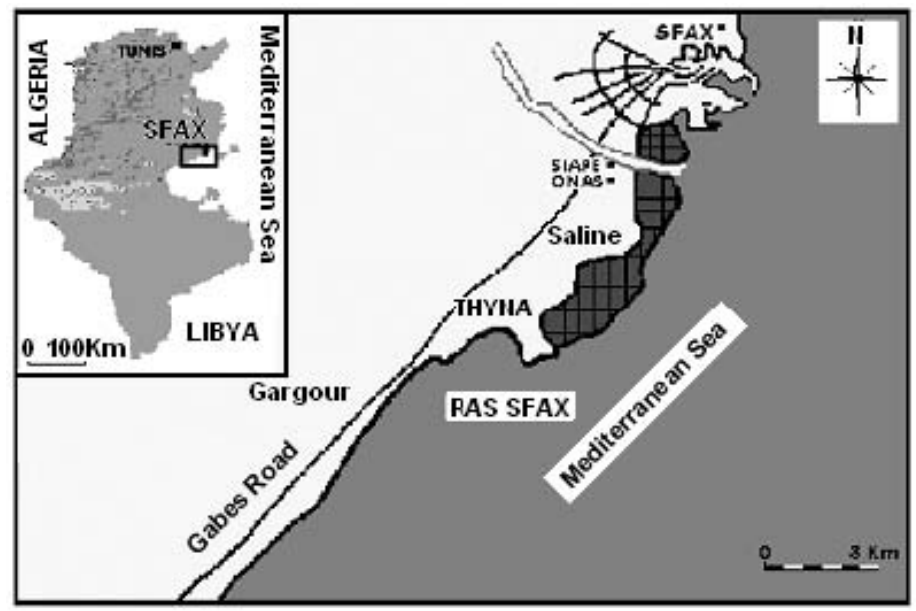

Figure 1. Location map of Sfax Saline.

The objective of this study is to follow the evolution of trace elements in seawater during the evaporation process. Factor "FC", that used, like reference scale, was calculated on a basis of Lithium content of seawater (Coast of Sfax) and those of the brines sampled in different ponds of the saline. The use of Lithium as a reference scale is justified by the fact that this element is not implied in any minerals of the saline paragenesis that precipitates during the progressive evaporation of brines.

\section{SAMPLING AND EXPERIMENTAL METHODS}

2.1. Sampling: Waters samplings have been achieved during two seasons (Autumn and spring). All the samples are free brines with the exception of those taken in the ponds of Magnesium chloride solutions that are interstitial brine. In addition, in the aim of discovering all salinity fields, some samples were obtained by evaporation in the laboratory.

2.2. Preparations and analyses: After filtration and acidification, trace elements in the brines were analysed by Electro-thermal Atomic Absorption Spectrometry with Zeeman Correction (HITACHI Z-7000). All analytical methods used were adapted to this environment of high salinity. The analytical problems caused by the high concentration of salts, have been surmounted by the use of the synthetic matrices and an adequate modifier (Amdouni, 1990). 


\section{RESULTS AND DISCUSSIONS}

3.1. Zinc behaviour: The behaviour of zinc in the seawater and in brines is remarkably dependent upon the $\mathrm{pH}$ (Long and Eangino, 1977). One distinguishes at least two different domains; for the $\mathrm{pH} \geq 8, \mathrm{Zn}(\mathrm{OH})_{2}$ is the most dominant species; for a neutral or acidic $\mathrm{pH}$ the chlorides complexes are the most predominant species. This difference in the speciation drives to a difference in the behaviour of zinc during the evaporative concentration of brines.

In the free brines of Sfax Saline the content in zinc varies between 2 and $25 \mu$ moles $\mathrm{kg}^{-1}$. From the seawater and until a concentration factor equal to 20 is reached, the concentration of $\mathrm{Zn}$ is very variable, but with a general tendency to the increase. In the most concentrated brines ( $F C \geq 20$ ), the content in $\mathrm{Zn}$ remains nearly constant (Figure 2). Such behaviour recalls the one of the sulphate ions (Amdouni, 2000).

In the beginning of the concentration process, the distribution of values detected in brines is due to the fact that the concentration of $\mathrm{Zn}$ is under biologic influence (the algae of the saline contain between 0.1 and 8 mmoles $\mathrm{kg}^{-1}$ of $\mathrm{Zn}$ ). From the same graphic we observed that in general the contents of $\mathrm{Zn}$ detected in May are superior to those measured in November. In ponds where the biologic activity is much reduced, the content of $\mathrm{Zn}$ that couldn't be precipitated, like a zinc salt, participle to the evaporative paragenesis only by co-precipitation with minerals phases. Indeed, zinc can mutually substitute with the metals group of magnesium-Iron thanks to the similarity in their ionic radius. The sodium chloride, deposited in crystallisers, contains between 10 and 25 $\mu$ moles $\mathrm{kg}^{-1}$ of zinc.

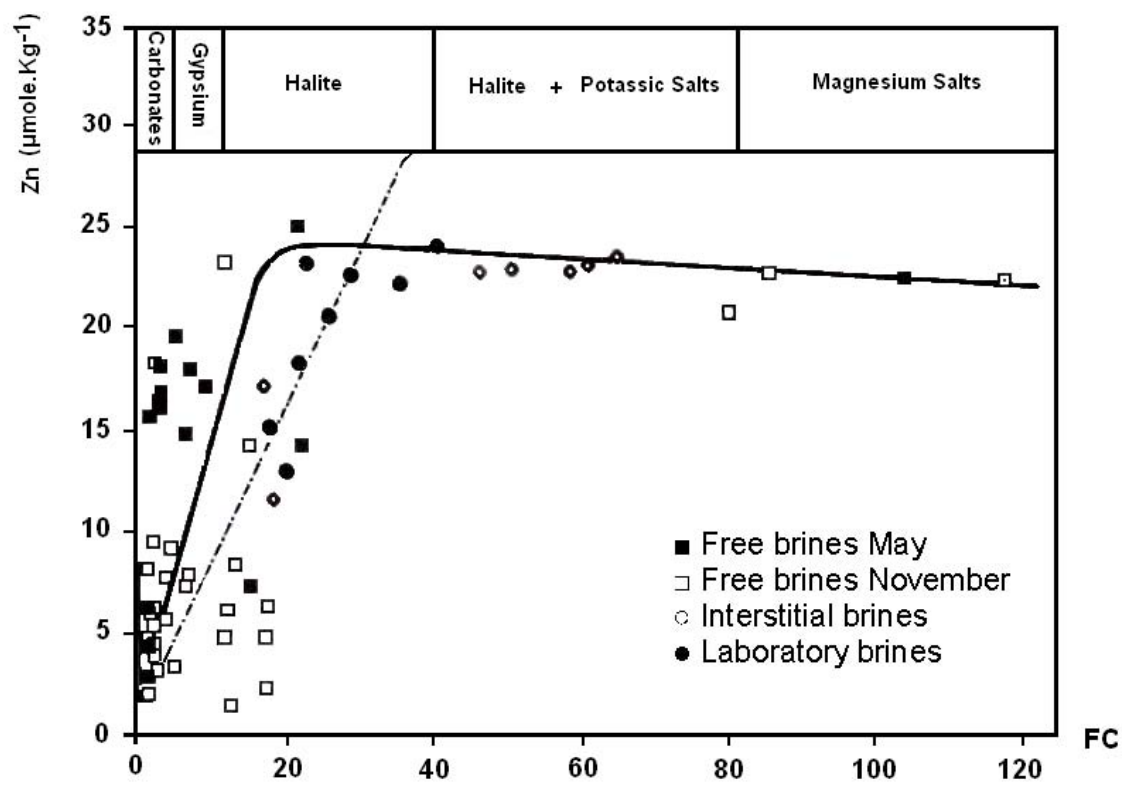

Figure 2. Evolution of Zinc concentration in brines of Sfax Saline

3.2. Cadmium behaviour: In the seawater the speciation of the cadmium is very close to those of zinc and it shows a big affinity for chlorides. According to the physico-chemical conditions $\left(\mathrm{pH}\right.$, temperature and salinity), several complex shapes $\left(\mathrm{CdCl}^{+}, \mathrm{CdCl}_{2}^{\circ}, \mathrm{CdCl}_{3}\right.$ and $\mathrm{CdCO}_{3}$ ) can appear in solution. In neutral or slightly acidic solutions, the speciation of the cadmium is extensively dominated by the chlorides complex (Long and Eangino, 1977).

In brines of Sfax Saline, the general evolution of the content in cadmium shows a certain resemblance to those of strontium and calcium (Amdouni, 2000). This analogy results in the similarity in their ionic radius, which permits the substitution of $\mathrm{Ca}$ in carbonates and gypsum by $\mathrm{Sr}$ and $\mathrm{Cd}$. The concentration in Cadmium, controlled in part by the biologic 
activity (the algae of the saline contains between 0.03 and 0.05 mmoles $\mathrm{kg}^{-1}$ of Cd), reaches a maximal value of 1 umoles $\mathrm{kg}^{-1}$ for a concentration factor equal to 14 and decreases until $0.05 \mu$ moles $\mathrm{kg}^{-1}$ when the solution becomes about 20 times more concentrated than the initial seawater (Figure 3). From the same graphic, we observe that for the same concentration factors the contents detected in November are superior to those measured in May. This seasonal variation (enrichment in November and impoverishment in May) could be explained by storage of the cadmium by the biologic system and its liberation after the death of micro-organism. In the densest brines, we record a certain stability of cadmium contents with a middle value of $0.03 \mu$ moles $\mathrm{kg}^{-1}$. The involvement of the cadmium to salts deposit is limited to its incorporation in gypsum and in the most soluble salts.

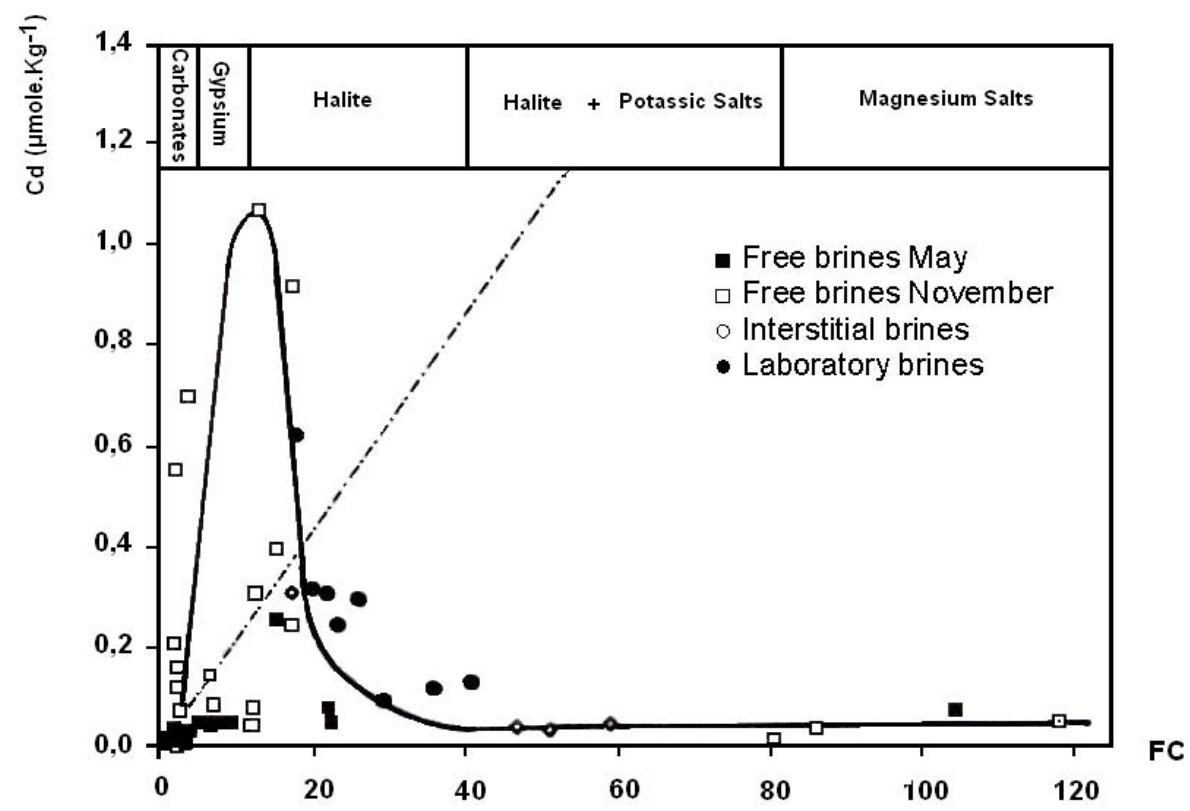

Figure 3. Evolution of Cadmium concentration in brines of Sfax saline

3.3. Manganese and the Molybdenum behaviours: In the natural waters the behaviours of manganese and molybdenum depend extensively on the physico-chemical conditions. Under the oxidizing conditions the $\mathrm{Mn}$ is immobilized by formation of an insoluble dioxide $\left(\mathrm{MnO}_{2}\right)$, whereas Mo remains in solution. Under the very reducing conditions $\mathrm{Mn}$ and Mo can be precipitated as sulphides and could be accumulated in the reducing sediments.

In the solutions of Sfax salt works, manganese and molybdenum show an identical evolution. This behaviour, similar to those of the potassium and the rubidium (Amdouni, 2000 ), indicates a possibility of mutual replacement between $\mathrm{K}, \mathrm{Rb}, \mathrm{Mn}$ and $\mathrm{Mo}$ in the crystalline networks.

In the initial solution of Sfax Saline, the concentration of manganese is about $0.18 \mu$ moles $\mathrm{kg}^{-1}$. This content evolves during the evaporation and reaches a maximal value of 25 $\mu$ moles $\mathrm{kg}^{-1}$ when the initial solution is almost 47 times more concentrated. Besides, the manganese concentrations detected in May are less than those measured in November. These seasonal variations that control the behaviour of $\mathrm{Mn}$ are in direct relation with the activity of the biologic system (the algae of the Saline contain until 0.9 moles. $\mathrm{kg}^{-1}$ of $\mathrm{Mn}$ ). In the densest brines, the concentration of $\mathrm{Mn}$ is controlled both by evaporation and by co-precipitation with the mineral phases. Therefore, the concentration of manganese decreases progressively until $0.7 \mu$ moles $\mathrm{kg}^{-1}$ (Figure 4). Crystals of salt contain between 15 and $300 \mu$ moles $\mathrm{kg}^{-1}$ of $\mathrm{Mn}$, with a remarkable enrichment in the potassium salts.

The content in molybdenum grows regularly in the beginning of the evaporation process (Figure 5) and reaches a maximal value of $8.7 \mu$ moles $\mathrm{kg}^{-1}$ for a concentration factor 
equal to 60 . This evolution is seriously affected in the domain of potassium salts where we observed a sudden decrease of the molybdenum concentration. There also we note the important seasonal variations being translated, as in the case of the manganese, by enrichment in November and an impoverishment in May. The involvement of Mo to the saline paragenesis is assured only by its co-precipitation with sodium chloride and especially with potassium salts that contain until $0.11 \mu$ moles $\mathrm{kg}^{-1}$ of Mo.

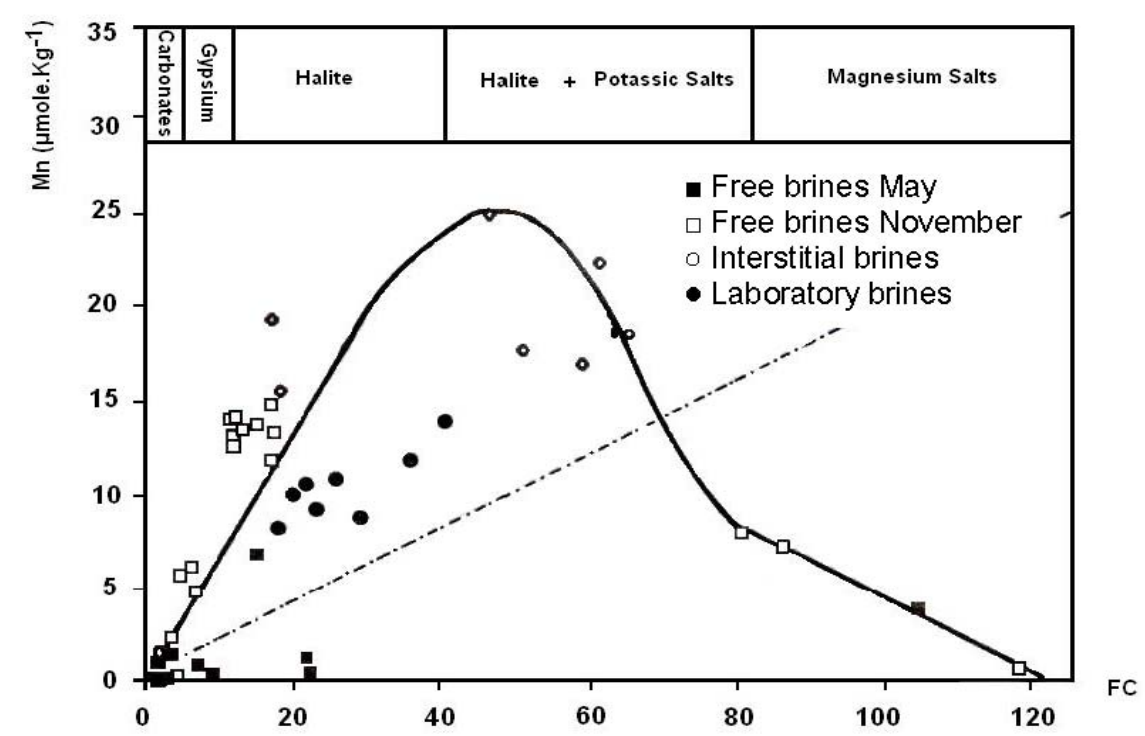

Figure 4. Evolution of Manganese concentration in brines of Sfax Saline

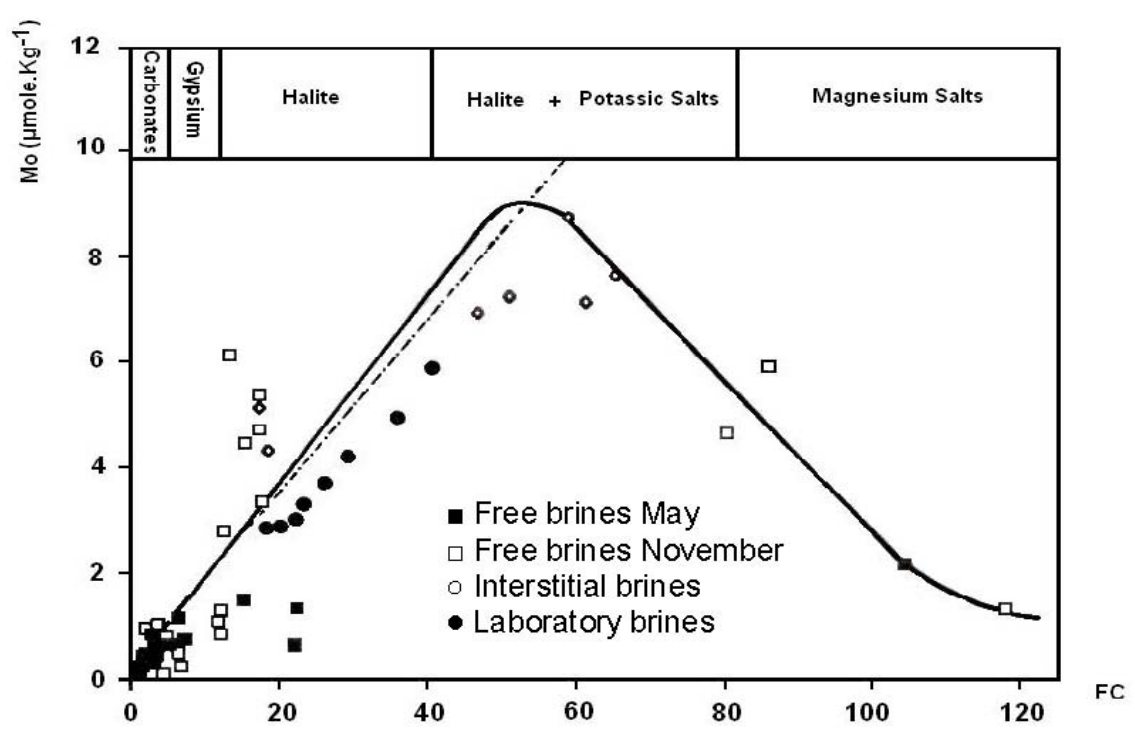

Figure 5. Evolution of Molybdenum concentration in brines of Sfax saline

3.4. Lead behaviour: The seawater sampled in coast of Sfax contains nearly 0.017 $\mu$ moles $\mathrm{kg}^{-1}$ of lead. This quantity, which superior to that detected in normal seawater, testifies again to the influence of the industrial dismissal (lead in dismissal waters is about $0.081 \mu$ moles $\mathrm{kg}^{-1}$ ) on the chemical quality of saline solutions.

In the zone where algae proliferate $(\mathrm{FC} \leq 20) \mathrm{Pb}$ contents are very variable because of the biologic intervention (algae contain between 0.08 and 0.16 moles. $\mathrm{kg}^{-1}$ of $\mathrm{Pb}$ ). In the domain of gypsum the increase of the concentration of lead can be assigned only to the evaporation effect. However, the content of $\mathrm{Pb}$ decrease in answer to its large involvement to the saline paragenesis, notably with the Potassium salts (Figure 6). This 
behaviour is expected because of the similarity of the $\mathrm{Pb}$ ionic radius to that of $\mathrm{K}$. For example, the German potash deposits contain 0.4 to $2.4 \mu$ moles $\mathrm{kg}^{-1}$ with about 0.8 to 1.3 $\mu$ moles $\mathrm{kg}^{-1}$ for the sylvite (Kuhn, 1968). This content varies from 0.2 to $1.2 \mu$ moles $\mathrm{kg}^{-1}$, in salt deposits in Sfax salt works.

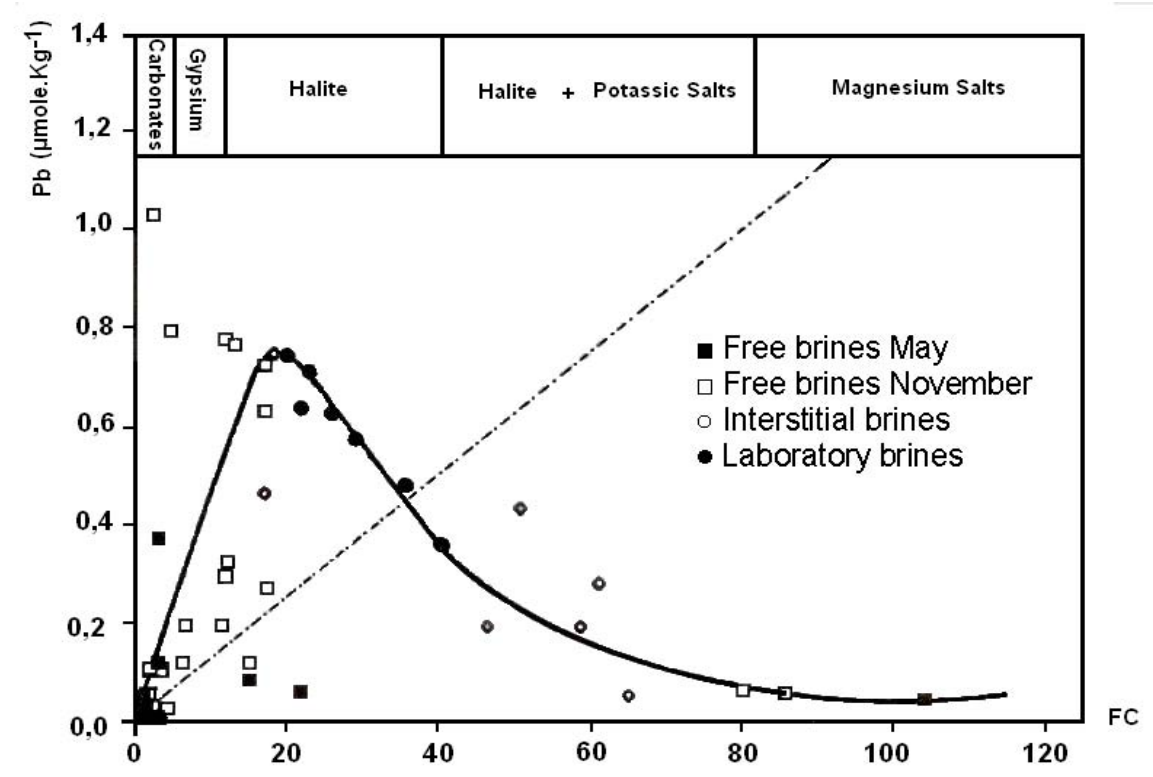

Figure 6. Evolution of Lead concentration in brines of Sfax Saline

3.5. Copper behaviour: The seawater sampled on the coast of Sfax, contains about $0.061 \mu$ moles $\mathrm{kg}^{-1}$ of copper. This very elevated value, in relation to that of normal seawater $\left(0.008\right.$ moles $\mathrm{kg}^{-1}$; Golberg, 1969), could be explained by the influence of industrial dismissal that contains about $0.068 \mu$ moles $\mathrm{kg}^{-1}$ of $\mathrm{Cu}$. In the most dilute solutions of the saline the copper is distinctly enriched with a maximum of $5.5 \mu$ moles $\mathrm{kg}^{-}$ 1 , reaches for a concentration factor equal to 10 (Figure 7). The variability of value, observed for these less concentrated brines, is due to the fact that the concentration of the copper is under biologic influence (algae contain between 0.12 and 0.24 mmoles $\mathrm{kg}^{-1}$ of copper). Such an influence results in the very important seasonal variations, because the storage of the copper by certain micro-organisms and its liberation after their death. It can be also greatly concentrated by accumulation under the reducing conditions. From the crystallisers and until the end of evaporative process $(20 \leq \mathrm{FC} \leq 120)$ the concentration of the copper in solutions is nearly constant and does not exceed 1 umoles $\mathrm{kg}^{-1}$. In this domain that is characterized by a total absence of the biologic activity the content of copper is under mineral influence. The salts deposits in the saline ponds contain between 1.6 and $16 \mu$ moles $\mathrm{kg}^{-1}$.

It is necessary to note that, like Lead, Copper is strongly complexed by chlorides and carbonates ions, even in the dilute solutions (Long and Eangino, 1977).

The general pace of the curve $\mathrm{Cu}$ versus FC recalls those of calcium and strontium (Amdouni, 2000). However, contents of copper in gypsum are below the detection limit of the used analytical methods. 


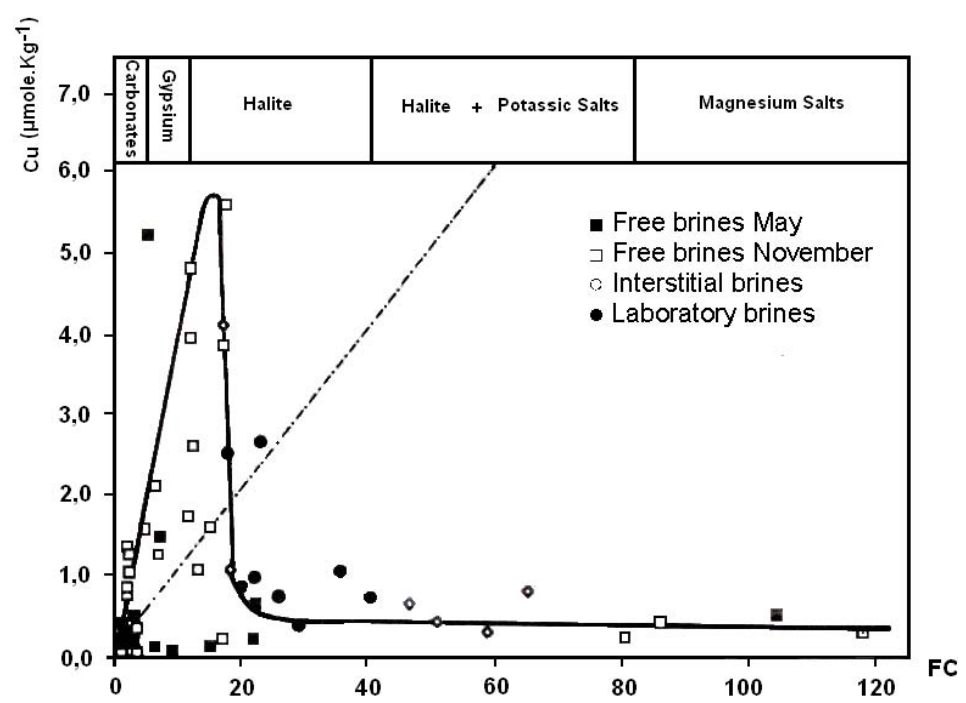

Figure 7. Evolution of Copper concentration in brines of Sfax Saline

3.6. Aluminium behaviour: The seawater of the Coast of Sfax, contains $5.53 \mu$ moles $\mathrm{kg}^{-}$ 1 of aluminium. During the evaporation process the behaviour of $\mathrm{Al}$ show a certain resemblance to that of the silica (Amdouni, 1990). In the less concentrated solutions (salinity $\leq 130 \%$ ) the dissolved aluminium content is subjected to the biologic influence that results in the important seasonal variations. These variations (enrichment in November and impoverishment in May) are in direct relation with the conditions of microorganisms life, notably diatomite and algae (algae mats contain 1.7 to $24.5 \mathrm{~g} \mathrm{~kg}^{-1}$ of aluminium) that use the aluminium in their biologic cycles. Also, it can be adsorbed on the sedimentary particles and in the organic matter (Moran and Moore, 1989). In basins where the biological activity seems to be very limited thanks to the increase of the salinity (salinity > $130 \%$ ), the evolution of the concentration of the aluminium would be due to the evaporation effect counterbalanced solely by adsorption and precipitation phenomena (Figure 8). In the evaporative paragenesis the aluminium can be met as a sulphate (simple or in association with $\mathrm{Na}$ and $\mathrm{K}$ ), as fluoride (cryolite, chiolite, fluellite,...) and in clays (mica-illite and kaolinite). It can be also substitute for the magnesium in magnesium silicates.

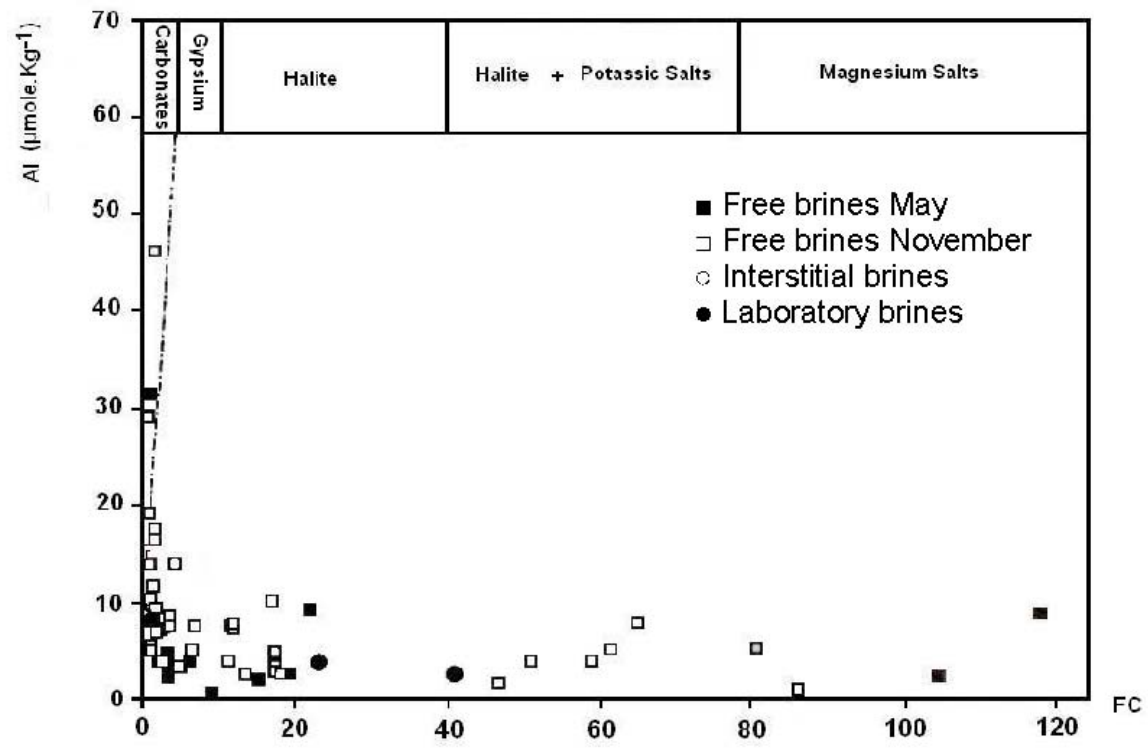

Figure 8. Evolution of Aluminium concentration in brines of Sfax Saline 
3.7. Iron behaviour: In the aqueous solutions the behaviour of iron is largely depending on its oxidization state. In the seawater and in neutral or slightly acidic waters, the ferrous Iron, that represents the totality of iron in solution, is present as a free ion $\left(\mathrm{Fe}^{++}\right)$or in association with the hydroxides, carbonates and sulphides.

In the first stage of evaporating process (salinity $\leq 140 \%$ ) the contents of iron in solutions are very variable. These variations are due to the activity of microorganism that uses iron in their biologic cycle. For example the algae mats contain between 11 and 250 mmoles $\mathrm{kg}^{-1}$ of iron. Besides, it can be adsorbed on the clayey minerals and on the superficial sediments (content of iron in sediments varies between 47 and 537 mmoles $\mathrm{kg}^{-1}$ ).

Iron fixed by algae or adsorbed on the sedimentary particles can be remobilized in interstitial waters and according to physico-chemical conditions of the environment it can precipitate as $\mathrm{FeCO}_{3}$ (in anaerobic environment) either as $\mathrm{Fe}_{2} \mathrm{O}_{3}$ (in aerobics environment) (Scheider and Herrmann, 1980). It is also possible that Iron dissolved in interstitial waters can migrate toward the surface. This migration of interstitial waters would explain the variability of its concentration in free brines (Figure 9). In the more concentrated solutions (salinity $>140 \%$ ), the content of Fe is very weak and for certain samples it is below the detection limit of the analytical method used to analyse Iron in brines (Amdouni, 1990).

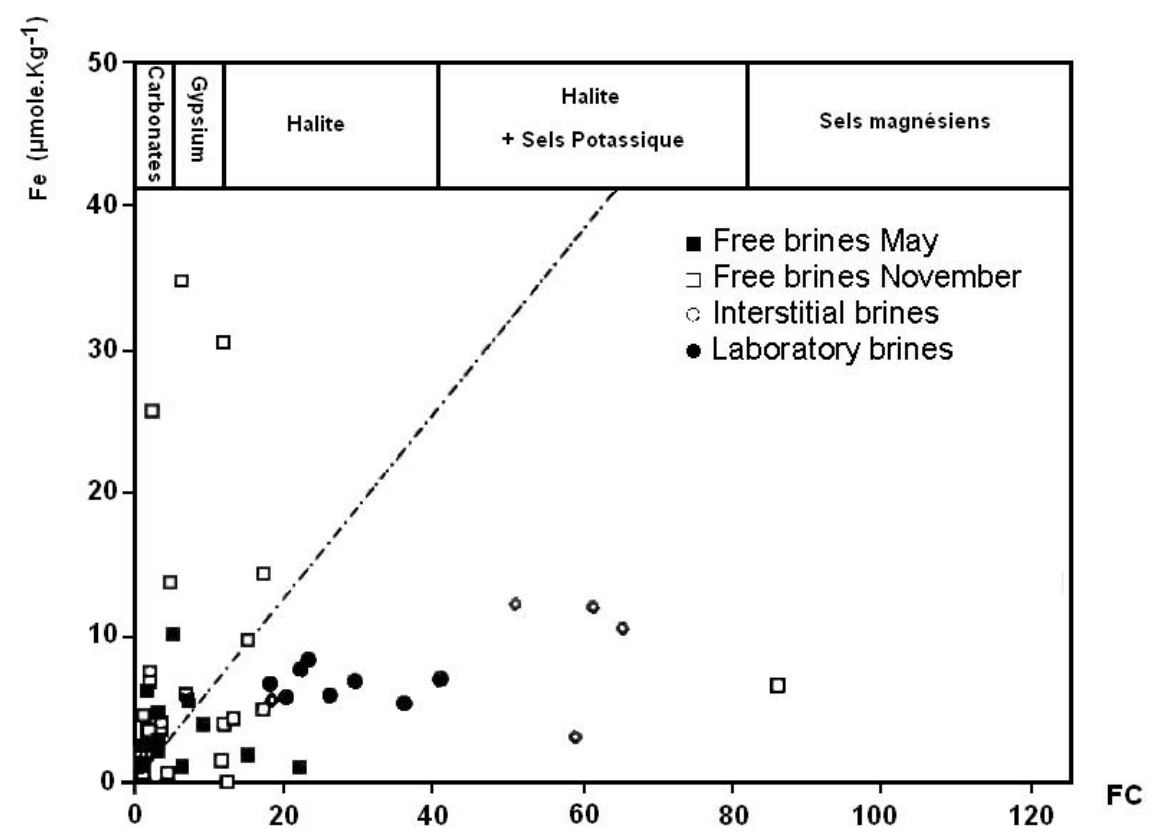

Figure 9. Evolution of Iron concentration in brines of Sfax Saline

3.8. Barium behaviour: In the beginning of evaporation process the concentration of the barium in brines tends to increase and reaches a maximum of $4 \mu$ moles $\mathrm{kg}^{-1}$ when the solution becomes almost 2.5 at 3.5 times more concentrated than the initial seawater. Nevertheless, we observe a sudden decrease of barium concentration and it seems to be controlled by a mineral phase. In fact, the barium can be associated to sulphates and carbonates ions to form barium sulphate $\left(\mathrm{BaSO}_{4}\right)$ and barium carbonate $\left(\mathrm{BaCO}_{3}\right)$. It is respectively the barite and the witherite, which are the only minerals of barium met in the saline paragenesis. The precipitation of these two minerals, that occurs since the beginning of chemical precipitation, is generally camouflaged, first by calcium carbonates then by gypsum. The seasonal variations observed for the concentration of brines in barium would probably be due to the involvement of this element (by replacement of the calcium) in the formation of carbonated tests, notably those of foraminifers.

From a concentration factor equal to 20 (domain of the halite), contents in barium become very weak and rarely exceed the $0.2 \mu$ moles $\mathrm{kg}^{-1}$ (Figure 10).

This behaviour, similar to those of the calcium and strontium (Amdouni, 2000), is 
expected because of the resemblance of their ionic radius, which favours their mutual replacement in the crystal networks.

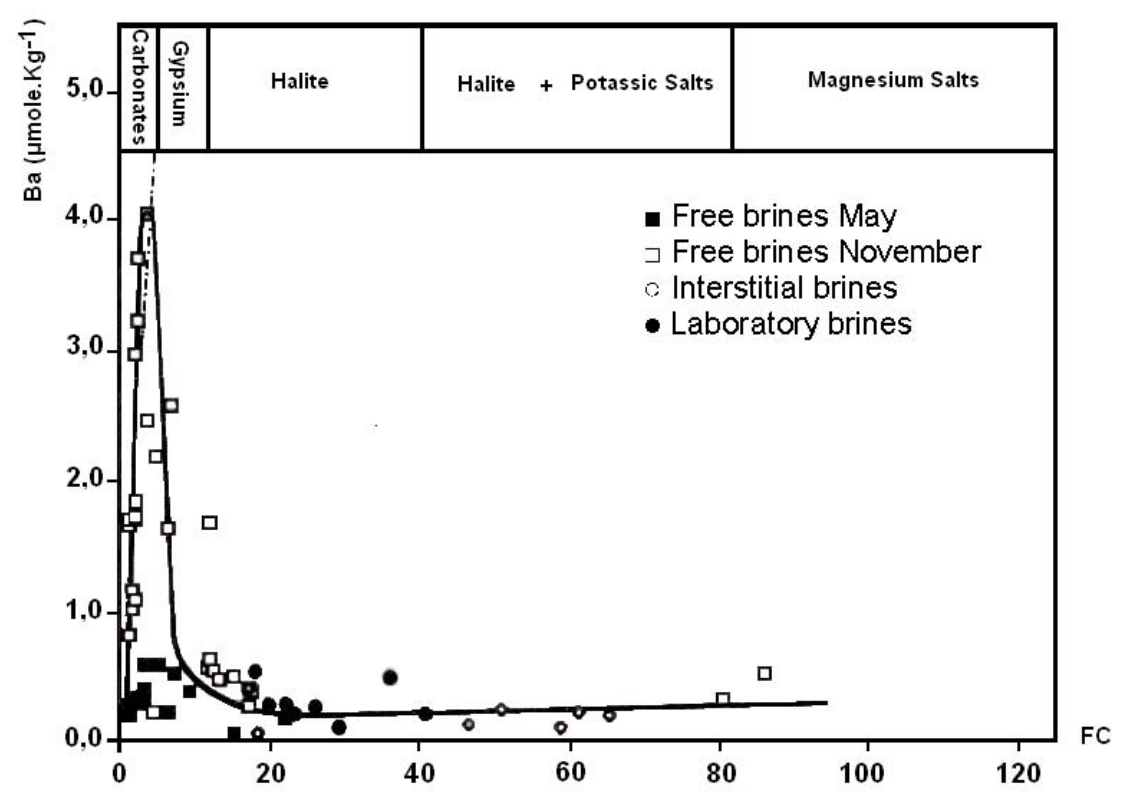

Figure 10. Evolution of Barium concentration in brines of Sfax Saline

\section{CONCLUSION}

From this survey, we can conclude that during the evaporation process, the concentration of trace elements in brines was affected by the evaporation phenomenon for the same reason as the major elements. Nevertheless, their concentrations remain very weak and don't reach their saturation doorsteps.

In the first stage of evaporating process, the evaporation effect is very limited and the behaviour of trace elements is under the direct influence of the biological activities, which colonize the first ponds of the Saline. This influence that results in the very important seasonal variations in the concentrations of these metals trace is mainly due to the physiological state of algae. Indeed, contents of metals detected in algae are not negligible and sometimes exceed extensively the concentrations present in the free brine of the same basin.

In the more concentrated brine, where the biological activity is absent or very limited because of the increase of the salinity, the evolution of several elements was controlled only by the evaporation-salt precipitation antagonist effect. However, in washed salt produced by the Sfax Saline, trace metals are present in quantity relatively very reduced compared to the tolerable limits fixed by the Food and Agriculture Organization (Amdouni et al., 1990). It is due to the fact that, in addition to the biologic activity that largely participates in the purification of the saline waters, the fractional crystallization, adopted in the production of sea salt, constitutes itself a purifying process.

\section{ACKNOWLEDGEMENT}

I would like to thank Mister Ben HMIDA M. and Mister AMDOUNI K. for the revision of the English manuscript. 


\section{REFERENCES}

1. Amdouni R. (1990), Etude géochimique des saumures libres, des sédiments et des sels dans la saline de Sfax (Tunisie), Thèse de l'Université Paris IV $237 \mathrm{p}+$ annexes.

2. Amdouni R. (2000), Chemical study of free brine in solar salt works of Sfax saline (E.S of Tunisia). $8^{\text {th }}$ World Salt Symposium The Netherlands 2000, vol. 1, pp. 501-506.

3. Amdouni R., Boulègue J. and Médhioub K. (1990), Influence de la pollution de l'eau de mer sur la qualité chimique de l'halite dans les cristallisoirs de la saline de Sfax (Tunisie), $2^{\text {ème }}$ congrès National des sciences de la Terre. Tunis 1990.

4. Amdouni R., Boulègue J. and Médhioub K. (1990), Intérêt de l'étude sédimentologique de la saline de Sfax dans l'interprétation des accumulations évaporitiques anciennes, (Tunisie), $2^{\text {ème }}$ congrès National des sciences de la Terre. Tunis 1990.

5. Golberg N. (1969), Differences between barite of marine and continental environments. Geochimi. Cosmoch. Acta, vol.33, pp.287-289.

6. Kuhn R. (1968), geochemistry of the German potash deposits ; Geol. Soc. Am. Spec. Papers Vol. 88, pp. 427-504.

7. Long D. T. and Eangino E. E. (1977), Chemical speciation of $\mathrm{Cd}, \mathrm{Cu}, \mathrm{Pb}$ and $\mathrm{Zn}$ in mixed fishwater, seawater and brines solutions. Geochim. Cosmochim. Acta. Vol. 45, pp. 553-561

8. Moran S. B. and Moore R. M. (1989), The distribution of colloidal aluminium and organic carbon in coastal and Open Ocean waters off Nova Scotia. Geochim. Cosmochim. Acta, vol. 52, pp. 2519-2527

9. Schneider J. and Herrmann A. G. (1980). Salt works. Naturel laboratoires for microbiological and geochemical investigations durant the evaporation of seawater. Fifth symposium on salt, Northern Ohio Geol. Soc., Vol. 2, pp. 371-381. 